\title{
Wine Making and the Politics of Identity in Alsace, 1918-1939
}

\author{
Alison Carrol \\ Department of Social and Political Sciences; Brunel University London, Marie Jahoda, Uxbridge UB8 3PH, UK \\ alison.carrol@brunel.ac.uk
}

This article examines the politics of wine making in Alsace in the two decades after the region returned to French rule in 1918. During these years Alsatian wine makers worked to transform their wines to meet the tastes of French drinkers, following five decades of producing wine for German consumption. As wine makers grappled with the question of how to secure the future of their industry, Alsatian wine became emblematic of the most contentious aspects of Alsace's reintegration into France. The introduction of new laws on viticulture raised the question of what was French about wine, the wine industry's woes symbolised the difficulties of Alsace's economic reintegration and wine became an emblem for often fierce wrangling over identity and belonging in the recovered region. This article traces this process and argues that while wine became a symbol of the complications of reintegration, its importance in understandings of French national culture equally allowed it to offer a solution to the problems that return to France caused for Alsace's wine industry in the interwar years. In this way, this case study of the politics of wine making in Alsace is suggestive of wine's broader power as a symbol of national belonging.

In June 1921 the monthly Bulletin of Alsatian and Lorraine Banking published a history of the brewing industry in the eastern French regions of Alsace and Lorraine. The Bulletin traced local breweries back to 1259 but focused on the period between 1871 and 1918 when Alsace-Lorraine was annexed into the German Empire. The article described the establishment of new breweries during these years, as beer from Baden and Bavaria flowed across the Rhine into the region's bars and beerhalls, where it filled the glasses of immigrants from 'old Germany'. In this vivid picture, the production and consumption of beer operated alongside the introduction of German systems, laws and institutions to integrate the region and its inhabitants into the mores and cultures of the German Empire, and differences between the local population and 'old German' migrants were gradually erased. In the words of the Bulletin, 'Germanisation through Beer' was underway. ${ }^{\text {' }}$

The idea of 'Germanisation through Beer' is suggestive of the connection between alcohol and questions of culture and belonging, and indicative of the ways in which alcoholic drinks hold rich potential to cast light on broader issues. Indeed, work on the history of alcohol has emphasised its importance as an emblem of wider economic, cultural and political questions, as well as its significance in shaping understandings of identity. ${ }^{2}$ And, the range of social actors involved in alcohol's production, trade and consumption means that it offers a useful lens through which to study broad historical

\footnotetext{
1 'L'Industrie de la Brasserie en Alsace et en Lorraine et dans l'ancienne France', Bulletin Financière de la Banque d'Alsace et de Lorraine, 25 June 1921.

2 Kolleen Guy, When Champagne Became French: Wine and the Making of a National Identity (Baltimore: The John Hopkins University Press, 2003); Thomas Thurnell-Read, ed., Drinking Dilemmas: Space, Culture and Identity (Abingdon: Routledge, 2015); Deborah Toner, Alcohol and Nationhood in Nineteenth-Century Mexico (Lincoln: University of Nebraska Press, 2015).

(c) The Author(s), 2020. Published by Cambridge University Press
} 
and contemporary processes across diverse geographical and chronological contexts. ${ }^{3}$ These issues adopt particular importance in the case of the history of wine in France; Marion Demoissier has emphasised the significant role of wine in constructing understandings of 'what it means to be French' and John Strachan has pointed out wine's potential 'to evoke specific passions and identity'. For Andrew Smith, meanwhile, wine's importance lies in its multiple strands of meaning: as the focus of sustained economic activity, the centrepiece of evolving social practice (in production and consumption) and as a canvas for depicting broader stories about culture, values and desire. ${ }^{5}$ Crucially, the centrality of wine to French culture and identity means that its history offers new ways of thinking about the evolution of ideas of Frenchness, as well as the role of wine producing regions in constructing understandings of the modern French nation.

The region of Alsace represents a useful case study for addressing such questions. In 1918 the end of the First World War triggered the region's return to French rule following almost fifty years of annexation into the German Empire. Upon recovering the region, the French government introduced new laws and administrative institutions, local and national economic elites worked to realign its economic systems to French structures and markets and battles began over the renegotiation of Alsace and Alsatian identities within the French nation. As reintegration rapidly adopted the form of a multicentred struggle, wine became emblematic of its most contentious aspects. Political discussion over the laws governing viticulture raised the question of what was French about Alsatian wine, the wine industry's woes symbolised the problems of Alsace's economic reintegration and wine became an emblem for often fierce wrangling over questions of belonging in the recovered region. As a result, wine making offers a useful case study for rethinking the dynamics of the process of reintegration, all the while casting a light upon broader questions of the role of alcohol in shaping understandings of identity and belonging. Yet the politics of wine have not been the subject of sustained research on the region's return to France and the process of Alsace's remaking as a French region. ${ }^{6}$

If the secondary research on Alsace after 1918 has not delved deeply into the role of alcohol in the region's reintegration, contemporary accounts are revealing of the prevalence of stereotypes of alcohol in propagating ideas of national belonging; most notably, the cartoons of Francophile artist Hansi frequently contrasted overweight Germans swigging beer with the sophisticated, wine-drinking French. ${ }^{7}$ Meanwhile, the diary of Alsatian schoolteacher Philippe Husser links wine to rumours about the end

3 Mark Hailwood and Deborah Toner, eds., Biographies of Drink: A Case Study Approach to our Historical Relationship (Newcastle upon Tyne: Cambridge Scholars Publishing, 2015).

4 Marion Demoissier, Wine Drinking Culture in France: A National Myth or a Modern Passion? (Cardiff: University of Wales Press, 2010), 29; John Strachan, 'The Colonial Identity of Wine: The Leakey Affair and the Franco-Algerian Order of Things', Social History of Alcohol and Drugs, 21, 2 (2007), 118-37, 118.

5 Andrew Smith, Terror and Terroir: The Winegrowers of the Languedoc and Modern France (Manchester: Manchester University Press, 2016).

6 Alcohol over the longue durée has been addressed by Claude Muller in a series of important books and articles, see in particular Claude Muller, Alsace. Une Civilisation de la Vigne. Du VIIIe siècle à nos jours (Strasbourg: Editions du Place Stanislas, 2010). It has been addressed in a more focused fashion as part of a study of alcohol in the context of social life during the years of the Kaiserreich by Jean-Pierre Hirsch in Vie de Bistrot en Alsace. Lieux de Loisirs et de Sociabilité 1844-1914 (Paris: Harmattan, 2012). However, wine has not been discussed in any detail in the large body of work which examines the political history of Alsace under French and German rule. See David Allen Harvey, Constructing Class and Nationality in Alsace, 1830-1945 (DeKalb: Northern Illinois University Press, 2001); Elizabeth Vlossak, Marianne or Germania? Nationalizing Women in Alsace, 1870-1946 (Oxford: Oxford University Press, 2010); Christopher Fischer, Alsace to the Alsatians? Visions and Divisions of Alsatian Regionalism, 1870-1939 (New York and Oxford: Berghahn Books, 2010). I have addressed the question of wine in terms of Alsace's economic reintegration in my own work. See Alison Carrol, The Return of Alsace to France, 1918-1939 (Oxford: Oxford University Press, 2018). However, I do not analyse the connections and tensions between economics and culture which lie at the heart of this article or focus upon the specific ways in which wine was mobilised to channel ideas about belonging.

7 For an overview and range of examples of Hansi's work see Jacques Feger, L'Alsace Heureuse par Hansi (Strasbourg: La Nuée Bleue, 2006) 
of the First World War, when he notes that the fact that the price of wine has 'dropped considerably' appears to support whispers that the region would shortly be returned to France. ${ }^{8}$ Of course, nothing was so straightforward, and the idea of 'beer drinking Germany' juxtaposed with 'wine drinking France' failed to capture Germany's important wine industry, as much as it overlooked significant French markets for beer, eau de vie and other spirits. Yet, such primary accounts do point to the importance of alcohol as a symbol of, or shorthand for, national identity. This symbolism was widely evoked in Alsace after 1918 in direct response to the challenges created by separation from Germany and attachment to France. Regional leaders, cultural intermediaries and commercial stakeholders emphasised long-term continuity alongside short term discontinuity in order to promote regional wines and to attempt to influence Alsace's process of reintegration.

This article explores the politics of wine in Alsace after its return to France in 1918 and underlines the ways in which this alcoholic drink reveals and refracts some of the problems of reintegration into French institutions and systems. ${ }^{9}$ Its focus is upon those discussions that took place within Alsace, where wine spoke directly to the question of what it meant to be a region of France, against the backdrop of the region's recent past as part of the supposedly beer drinking German Empire - and where the politics of wine not only reflected, but also contributed to, the frequently tense nature of return. The first section addresses the social and economic dimensions of the wine industry upon its return to France, as wine makers confronted their new national market and, specifically, the question of how to realign Alsatian wines to the tastes of French drinkers. Section two moves on to the legal implications of reintegrating wine, and to the ways in which the laws around wine production became a political issue that reveals the interactions between different stakeholders in the reintegration process. Finally, the third section discusses the cultural dimensions of the interwar wine industry, as well as the tensions that emerged between ideas of wine as a component of national and regional identity and the demands of economic reintegration. All three sections highlight the interactions and tensions between the various dimensions of Alsace's reintegration into France and are suggestive of the diverse understandings of Frenchness that were channelled by discussions over Alsatian wine. These debates underline that things were far more complicated than the notion of 'Germanisation through beer' would suggest. Indeed, efforts to 'Frenchify through wine' (to borrow the idea) were characterised by diverse understandings of what, exactly, was French about both wine and Alsace.

\section{The Social and Economic Dimensions of Wine Making}

Wine has long represented an important element of the Alsatian regional economy. In 1920 vineyards covered 26,000 hectares of Alsatian land, lining the lower eastern slopes of the Vosges mountain range running between Marlenheim in the north, down to Thann in the south of the region, with most vines concentrated in the southern department of the Haut-Rhin. ${ }^{10}$ For much of the early twentieth century Alsatian wine makers were generally small producers. In 1933 Adolphe Walter, the President of the Association of Alsatian wine makers (vignerons), compiled a report on the state of the regional wine industry as part of a major overview of the region's return to France. In it, Walter offered the 1907 statistics on the size of Alsatian vineyards as the most recent available but noted that the situation had 'changed little' in the intervening years. According to Walter, 59,229 of the region's vineyards were less than one hectare in size, while 3,937 were between one and two hectares and 1,050 were more than

\footnotetext{
8 Philippe Husser, Un Instituteur Alsacien. Entre France et Allemagne: Le Journal de Philippe Hussuer, 1914-1951, Avant Propos de Frank Ténot, Présentation de Alfred Wahl (Strasbourg: La Nuée Bleu, 1989), 115.

9 A section of the neighbouring region of Lorraine was also annexed into the German Empire, and then reintegrated into France as the department of the Moselle. While the Moselle shared the experience of annexation and return, its wine industry was distinct from that in Alsace and it faced very different challenges. As a result, this article focuses only on Alsace. On the Moselle, see Carolyn Grohmann, Problems of Reintegrating Annexed Lorraine into France, 1918-1925, University of Stirling, Unpublished PhD Thesis, 2000

10 'Les richesses minières de l'Alsace-Lorraine', L'Evenement, 25 May 1920.
} 
two hectares. ${ }^{11}$ The small size of Alsatian vineyards reflected the fact that most producers were small-scale, family enterprises.

Alsatian vineyards co-existed alongside hop fields and breweries, and Alsace was unusual amongst French regions as an important producer of both wine and beer. The two crops were not grown side-by-side, however, and were to be found in different parts of the region, with vineyards centred in the Catholic areas of the Haut-Rhin and hops grown mainly in the northern department of the Bas-Rhin around the communes of Strasbourg-Campagne, Haguenau and Wissembourg. Like grapes, hops represented an important element of the regional economy and spurred growth in related industries such as the production of accessories including tools, trellises, dryers and packing cloths. But hop growers faced separate challenges to those which confronted vignerons after 1918, and the differences were rooted in large part in the distinct positions occupied by wine and beer in French national cultures of consumption, as the nineteenth century had seen a growing presentation and understanding of wine as the French national drink. As Kolleen Guy has pointed out, the apparently eternal qualities and values attributed to the French nation have also been applied to its wines, with the result that wine and national identity have become 'so intertwined that it is now difficult to invoke one without eliciting the other. ${ }^{12}$ These qualities also encompassed the producers of wine, with vignerons anchoring regional identities in the idea of terroir, a uniquely French concept that brought together ideas of climate, soil, location and the soul of the vigneron. The resulting terroir was both natural and eternal and was central to ideas about French wine. ${ }^{13}$

In 1871 Alsace was annexed into the German Empire along with the north-eastern section of Lorraine (the current department of the Moselle) in the aftermath of the Franco-Prussian War. The Imperial government introduced new laws, administrative institutions and policies intended to disseminate German culture and language. ${ }^{14}$ As Alsace was gradually integrated into the institutions and systems of the Kaiserreich, France embarked upon the consolidation of the Third Republic, created in the aftermath of its defeat. The construction of railways, introduction of compulsory primary schooling and military service, dissemination of the French language and creation of a national culture all contributed to the emergence of a sense of Frenchness in France's regions. Equally, local populations played an important part in filtering national values through existing understandings. ${ }^{15}$ Meanwhile, a group of Alsatian émigrés kept alive the idea of the so-called 'lost provinces' of Alsace-Lorraine, through monuments, literature and art which depicted the region as eternally French and awaiting its liberation by France. This became known as the cult of Alsace-Lorraine. ${ }^{16}$ Alcohol took on an important role in this cult, but it was beer rather than wine that adopted pride of place as Alsatian brasseries opened in Paris and across France after 1871, and which created an imagined association between Alsace and beer drinking in the French 'interior'. ${ }^{17}$

The years of Alsace's annexation into Germany equally represented a period of profound change for French wine. Wines began to find markets beyond regional borders and were protected and

11 A. Walter, 'Le vin' in Comité alsacien d'études et d'informations, L'Alsace depuis son retour à la France. 3 Vols. Vol 2. La vie économique (Strasbourg, 1933) 175-182, 175.

12 Guy, When Champagne became French.

13 Philip Whalen, “Insofar as the ruby wine seduces them”: Cultural Strategies for Selling Wines in Interwar Burgundy', Contemporary European History 18, 1 (2009): 67-98, 76.

14 Dan P. Silverman, Reluctant Union: Alsace-Lorraine and Imperial Germany, 1871-1918 (University Park: Penn State University Press, 1972).

15 Eugen Weber, Peasants into Frenchmen: The Modernization of Rural France, 1870-1914 (Stanford: University of California Press, 1976); Caroline Ford, Creating the Nation in Provincial France: Religion and Political Identity in Brittany (Princeton: Princeton University Press, 1993); Timothy Baycroft, Culture, Identity and Nationalism: French Flanders in the Nineteenth and Twentieth Centuries (Woodbridge: Boydell and Brewer, 2004).

16 Laurence Turetti, Quand la France pleurait l'Alsace-Lorraine: Les 'provinces perdues' aux sources du patriotisme républicain, 1870-1914 (Strasbourg: La Nuée Bleue, 2008).

17 Alfred Wahl et Jean-Claude Richez, La Vie Quotidienne en Alsace entre France et Allemagne, 1850-1950 (Paris: Hachette, 1993). 
promoted by laws that assured their quality and provenance. ${ }^{18}$ Yet these years were also the years of 'wine crisis' (crise du vin'), as three biological blights attacked the leaves, fruit and roots of French vines. The most devastating, the phylloxera epidemic of 1863 to 1900 , was overcome only by grafting French vines onto American roots. After their recovery from phylloxera, French vignerons suffered additional setbacks caused by overproduction, increased production costs and additional competition from Australia and Algeria.

In Alsace, wine making during this period was targeted at German drinkers, and the years of annexation saw more than 200,000 hectolitres of Alsatian wine sold in the Kaiserreich every year. ${ }^{19}$ What is more, Alsatian wine was transformed by German laws, which allowed the addition of sugared water (sugaring) and of grapes from another region (blending). These additions were permitted on condition that sugared water did not exceed a proportion of four to one, and that the added grapes did not make up more than 49 per cent of the finished product. ${ }^{20}$ This created an important difference between Alsatian wines and those produced in France, where wine laws specified that wines produced through these means needed to be specifically labelled as such. Both techniques were equally controversial in Germany, where the late nineteenth century saw lively debates over so-called artificial wines, which, as Kevin D. Goldberg has pointed out, frequently placed Jewish merchants at their centre. ${ }^{21}$

The backdrop to debates over wine quality was the effort of certain regions to produce quality wines. Indeed, the centrality of the Rhine River and Rhinelands to German nationalism meant that there was space for wine in cultural constructions of Germanness that was not recognised in the stereotype of beer drinking Germany. Celia Applegate has analysed efforts to promote Pfälzer wine as 'the leading product' of the Palatinate through a series of measures including the creation of a wine museum that linked Pfälzer wine to the local character, and which stressed the apparently eternal qualities of the drink by drawing a line of continuity back to the wines produced in the region by the Romans. ${ }^{22}$ Alsace was incorporated into such efforts through wine fairs and celebrations, such as the German Wine Congress, which was held in Colmar in 1900.

When the First World War broke out in 1914 the French army advanced into Alsace in August of that year. The wine industry suffered from the devastation of the landscape, as well as the dislocation caused by shortages of labour when men were conscripted into the army. Wine makers were not alone in this experience; regional industry in general was badly affected by the war, and Alsatian brewers were hit as hop growers abandoned production and the imperial government requisitioned copper brewing instruments. Following the dislocation caused by the war, fresh problems emerged when the Armistice triggered the return of Alsace to France, and the wine industry needed to realign itself towards French markets, laws and cultures of consumption.

At first, the return to France appeared to present opportunities for Alsatian vignerons, not least as it promised access to large numbers of new customers in France. It was hoped that this would more than offset the loss of Germany, which consumed far more beer than wine. ${ }^{23}$ But Alsatian vignerons faced a series of problems following the region's return. The 1920s were a decade of overproduction across France, combined with a series of bad harvests in Alsace in 1920, 1921, 1923, 1924, 1925, 1926 and $1927 .{ }^{24}$ Meanwhile, the 1930s saw the onset of a deep-rooted economic depression, as well as the continuation of difficult harvests caused by poor weather conditions. In 1938 almost all of the region's

\footnotetext{
18 Strachan, 'The Colonial Identity of Wine', 126.

19 Walter, 'Le vin', 179.

20 Minutes, Apr. 1921, Archives Departementales du Bas-Rhin (Hereafter ADBR) 121AL 1260 Conseil Consultatif d'Alsace et Lorraine, Session d'Avril 1921. Procès Verbal.

21 Kevin D. Goldberg, 'Reaping the Judenfrage: Jewish Wine Merchants in Central Europe before World War I', Agricultural History, 87, 2 (2013), 224-45.

22 Celia Applegate, A Nation of Provincials: The German Idea of Heimat (Berkeley: University of California Press, 1990), 72, 98-9.

23 Franz Meussdoerffer, 'Beer and Beer Culture in Germany', in Wulf Schiefenhövel \& Helen Macbeth, eds., Liquid Bread: Beer and Brewing in Cross-Cultural Perspective (New York \& Oxford: Berghahn Books, 2011), 63-70.

24 Muller, Une Civilisation de la Vigne, 257.
} 
grapes froze on the vines in two nights of freezing conditions on 21 and 22 April. ${ }^{25}$ These problems intersected with the far more significant issues presented by the fact that neither French nor German customers were buying Alsatian wine in the numbers required to sustain the business.

The latter problem resulted from the fact that Alsatian vignerons had spent the previous decades producing wine to meet the tastes of German consumers, and these wines did not appeal to French drinkers, who reportedly found them to be too 'acidic'. ${ }^{26}$ This problem was compounded by the region's terrain and the financial implications of moving from the German mark to the French franc, meaning that cost of maintaining vines and producing wine in Alsace was higher than in the rest of France. This made Alsatian wines prohibitively expensive when producers attempted to sell them to consumers across the Vosges: in the words of the President of Strasbourg's Chamber of Commerce, French consumers did not buy Alsatian wines as they found them to be 'too green, too acidic and too costly'. ${ }^{27}$ And, to make matters worse, Alsatian vignerons could not rely on locals to buy their products; a 1921 session of the Alsatian Advisory Council (conseil consultatif) despairingly noted that even Alsatian wine dealers bought 'almost all' of their wines from the interior. ${ }^{28}$

What is more, Alsatian wines failed to retain their markets in Germany during the transition period allowed by articles 68 and 268 of the Treaty of Versailles, which permitted Alsatian and Lorrain producers to send goods to Germany without paying import duty for a five-year period. This dispensation was on the condition that the level of Alsatian and Lorrain exports did not exceed the annual average of exports recorded between 1911 and 1913. Unfortunately for Alsatian vignerons, the transition period coincided with a rapid depreciation of the German mark and a boycott of French goods in protest at the occupation of the Ruhr by the French army. As a result, Alsatian and Lorrain producers struggled to export their goods at the levels envisaged at the Peace Conference. For the region's wine makers, this meant that exports of Alsatian and Lorrain wines dropped from 62.2 per cent to 9.2 per cent of their total product between 1920 and 1922, as German consumers purchased just 180,000 hectolitres of wine from the recovered departments between January 1920 and January $1921 .^{29}$ But, as we have seen, regional wines were not able to replace these lost markets with new consumers in the French interior or existing customers in Alsace.

Other sectors of the economy similarly faced challenges after 1918, yet the particular place occupied by wine in French national culture created a unique set of challenges for wine makers. Thus, brewers seized the initial opportunities offered by new access to French markets while profiting from the closure of Alsace and Lorraine to Baden and Palatinate brewers. These changes allowed sales of Alsatian beer in France to reach 100,000 hectolitres shortly after return, and imports from Germany dropped from the pre-1914 figure of more than 400,000 to a few thousand hectolitres. ${ }^{30}$ In this environment beer production in Alsace increased from 4,560 hectolitres per year in 1912 to 10,068 in 1930, while taxes on beer represented 701,000 francs in 1922 and 4,962,000 francs in 1931. ${ }^{31}$ Beer's story was not an unmitigated success, however, as Alsace produced twice the amount of hops needed by French breweries and was hit further by competition from new centres of hop growing in Poland and Yugoslavia. As a result, hop growers found themselves in the midst of an overproduction crisis by the end of the 1920s. Meanwhile, beer consumption lingered at four fifths of its pre-war level. The result of this situation caused prices per $100 \mathrm{~kg}$ to drop from 6,620 francs in 1926 to 1,200 francs

\footnotetext{
25 Ibid., 259.

26 Minutes, Apr. 1921, ADBR 121AL 1260 Conseil Consultatif d'Alsace et Lorraine, Session d'Avril 1921. Procès Verbal.

27 Letter, 20 Apr. 1920, ADBR 121AL 1261 Président de la Chambre de Commerce de Strasbourg to Directeur des Services du Commerce et de l'Industrie.

28 Minutes, Apr. 1921, ADBR 121AL 1260 Conseil Consultatif d'Alsace et Lorraine, Session d'Avril 1921. Procès Verbal.

29 Letter, 27 June 1921, ADBR 121AL 1261 Le Commissaire Général de la République to Président du Conseil, Strasbourg; Letter, 30 Apr. 1923, 121 AL 1261 Commissaire Général de la République to Monsieur le Garde des Sceaux, Ministère de la Justice, Paris.

30 Charles Kleinknecht (Ingenieur-Brasseur), 'La Brasserie', Le retour de l'Alsace à la France, vol. 2. La vie économique (Strasbourg, 1933), 144-9, 145-6.

31 Ibid., 144-9, 147.
} 
in 1928 and 350 francs by $1929 .{ }^{32}$ In response, Alsatian hop growers reduced their production. This allowed an increase in prices which hit 1,300 francs per $100 \mathrm{~kg}$ in 1932, and the brewing industry began a faltering recovery in the $1930 \mathrm{~s}^{33}$

Alsatian vignerons similarly attempted to overcome the trials of the 1920 s by reducing production, principally by replacing their hybrid plants with quality vines capable of producing superior wine that they hoped would meet the tastes of French consumers. But, before doing so, this question generated lively debates over whether vineyards should continue to make 'everyday' wine produced from hybrid plants, or whether they should switch entirely to quality vines. Ultimately, it was the overproduction crisis that peaked in 1929 which tipped the balance decisively in favour of quality plants. The decision to move away from hybrids meant a reduction in the number and scale of vineyards in Alsace, as land used for vine growing dropped from 18,804 hectares in 1919 to 11,344 hectares in $1938 .{ }^{34}$ Other measures to improve quality included the use of industrial filters and the creation of the Union for the Production and Sale of Alsatian Wine (Union de la Production et du Commerce des Vins d'Alsace), which worked to improve the quality of the region's wines and to promote them through local wine fairs.

As they discussed the problems that they faced, vignerons, wholesalers, the Chambers of Commerce and conseils consultatifs put their difficult situation down to practicalities, citing the taste of Alsatian wine on the one hand, and the issues with exporting on the other. Nonetheless, the problems that the Alsatian wine industry faced after 1918 cut to the heart of the questions posed by the region's return to France and its on-going relationship with Germany. If its position on France's eastern border meant that Alsace had longstanding economic and cultural connections to Germany, all involved in the wine industry recognised that its primary relationship needed to be with France. But French drinkers were tasting Germany in what they expected to be French bottles of wine, and wine sales suggested that the experience was not a pleasant one. This prompted the question of altering Alsatian wine to meet French tastes, as well as the laws that framed the position of Alsatian wine within French markets.

\section{The Laws Regulating Wine Making}

The predicament faced by the Alsatian wine industry raised important political questions about the region's relationship to France, as well as about relations between France and Germany. Crucially, discussions over how to sell Alsatian wines in the French interior posed the question of the laws governing the wine industry, and which French laws should be applied to Alsace and the Moselle. As the French Republic had been founded on the principle of uniformity, a central issue was whether Alsace could retain its local laws, or if French wine laws needed to be introduced in their entirety. As such discussions progressed, they also revealed the difficult balancing act that the French authorities faced in mediating between the needs of producers, wholesalers and different political interest groups with a stake in reintegration, both in Alsace and in the French interior. Equally, as vignerons represented an important electoral constituency, their frustrations with the situation meant that wine became a symbol of disconnection and of the failures of reintegrating Alsace into France. What is more, the continued importance of German markets for Alsatian wines meant that the issue followed the ebb and flow of Franco-German relations and raised questions over the implications of the Versailles Peace Treaty throughout the 1920s.

Alsace returned to France with a patchwork of pre-1871 French laws and German Imperial laws, and the majority of discussions over the legislation governing Alsatian wine focused upon two laws introduced during the region's years of German rule; the first concerned sugaring (sucrage - adding sugar or sugared water), to encourage fermentation and improve taste, and the second permitted

\footnotetext{
32 Walter Rinckenberger (Docteur en Droit), 'Le Houblon', Le retour de l'Alsace à la France, vol. 2. La vie économique (Strasbourg, 1933), 183-6,185.

33 Ibid., 185.

34 Muller, Une Civilisation de la Vigne, 257.
} 
blending with grapes from other regions (coupage) to improve taste and strength. While both were permitted under the German laws still in force in Alsace in 1918, French law specified that wine produced in this way needed to be clearly labelled as such and could not be marketed as wine. This provoked the question of whether the German legislation should be repealed and replaced with its French equivalent, or whether the practicalities of wine making in Alsace meant that the German legislation should be left in place (on a temporary or a permanent basis) to avoid the total decimation of the wine industry. Answers to these questions did not prove straightforward, and different stakeholders offered a range of solutions.

Alsatian wine makers argued that sucrage was necessary to allow their wines to compete with wines from the German Rhineland, which were produced using similar grapes and terrain, and which contained added sugar. Some vignerons suggested a temporary dispensation which would allow sugaring to continue while they worked on replacing their existing plants with new, quality vines better suited to the tastes of French consumers. ${ }^{35}$ For other vignerons, sucrage should be maintained permanently. The prominent Catholic politician abbé Xavier Haegy spoke for this section of producers when he argued that the 'natural market' for Alsatian wines was in Germany as their wines shared the characteristics of Rhineland and Mosel wines, which were treated with sugar, and as a result the same treatment should be applied to Alsatian wines. ${ }^{36}$ In Haegy's view, Alsatian vignerons should not attempt to realign their production towards French markets and instead should focus upon retaining and developing their markets in Germany. Wholesalers countered that the addition of sugared water gave the region's wines a bad reputation and stressed that this was a particular problem for Alsatian wines, which were seeking to restore their reputation within France. As a result, they called for the immediate introduction of the French law, which prevented the sale of drinks produced in this way as wine. ${ }^{37}$

The problem was complicated by the fact that while Alsatian sugared wines were prohibited from being sold as wine in France, this did not apply to wines produced in the same way from the German Rhineland. This anomaly, combined with the weakness of the German mark, gave Rhineland wines an edge over their Alsatian competitors. By 1921 labelling to show how wine had been produced was introduced in an effort to resolve this problem, but it did not have the desired effect. ${ }^{38}$ As a result, discussions over the issue were protracted, and when a law was finally ratified in August 1921 it applied French legislation to the recovered departments 'in its entirety'. Nonetheless, the 1921 law contained an important concession that permitted sucrage, as long as the sugared water was added according to the proportions allowed by the local law, the wine's label was clear on its means of production and it was sold only in the recovered departments or abroad. ${ }^{39}$ This allowed the addition of sugar 'as required' and up to 50 per cent to achieve a wine equivalent to that of a good year. ${ }^{40}$ This disposition was allowed until 31 December 1925, with the hope that this transition period would grant the vignerons sufficient time to adapt to French markets. ${ }^{41}$

The law on coupage (blending) permitted wines to be improved by the addition of grapes from outside the region, as long as the added grapes made up less than 49 per cent of the finished product. This technique was primarily used for red rather than white wine. Like the law on sucrage, this was incompatible with French law which allowed any percentage to be added but prohibited any blended wine from receiving the AOC label (appellation d'origine contrôlée, a geographically delimited quality

\footnotetext{
$\overline{35}$ Minutes, Apr. 1921, ADBR 121AL 1260 Conseil Consultatif d'Alsace et Lorraine, session d'Avril 1921. Procès Verbal. 36 Ibid.

37 Report, 6 July 1920, ADBR 121AL 1260 Le Syndicat du Commerce en Gros des Vins du département du Haut-Rhin.

38 Letter, 26 Dec. 1921, ADBR 121AL 1261 Président de la Chambre de Commerce de Colmar to Directeur des Services du Commerce et de l'Industrie, Colmar.

39 Minutes, 26 Aug. 1921, ADBR 121AL 1260 Journal Officiel, (Law of 25 Aug. 1921, signed Président de la République, Alexandre Millerand); Newspaper Article, 3 Dec. 1921, 'Le Nouveau Régime des Vins. Déclaration de récolte et sucrage', La Correspondance de Strasbourg.

40 Newspaper Article, 3 Dec. 1921, Le Nouveau Régime des Vins. Déclaration de récolte et sucrage, La Correspondance de Strasbourg.

41 Letter, 28 Apr. 1925, ADBR 121AL 1260 Ministre des Finances to Président du Conseil, Paris.
} 
mark). In the eyes of Alsatian vignerons, achieving the AOC was to be an important marker of the reintegration of the region's wine industry.

The debate over this piece of legislation split the recovered departments, with the wine makers of Alsace and the Moselle adopting divergent positions. Its principal use to improve red wine meant that it was rare in Alsace, where the main product was white, but it was widespread in the Moselle, where most vignerons produced red wines. The two departments split when Mosellan vignerons demanded its retention. ${ }^{42}$ The guild of Lorrain wine wholesalers called for an aggressive use of Versailles articles 68 and 268 which allowed Alsatian and Mosellan producers to send their goods to Germany without import duty for five years after the ratification of the treaty. They argued that the vignerons should then use their profits to modernise their methods and replace their plants with fine grapes in time for the closure of German markets to Alsatian and Mosellan goods in 1925. This, they argued, would allow a return to the reputation that Mosellan wines enjoyed before 1870 when they were 'celebrated' for their 'fine and delicate' character and commanded a higher price amongst French consumers than they did amongst Germans. ${ }^{43}$

Alsatian vignerons adopted the contrary position on blending and called for the immediate introduction of the French law on the practice. Some stressed that they did not profit from the sale of wine produced in this way and argued that the practice damaged the reputation of all regional wines. ${ }^{44}$ Others, meanwhile, pointed to the important market for Alsatian wines in Germany, and stressed that while Alsatian and Mosellan goods were exempt from customs duty if they were exported into Germany (under the terms of the Treaty of Versailles), the addition of more than 50 per cent of grapes from another region would mean that customs duties would be applied. ${ }^{45}$ In 1920 the conseil consultatif adopted an amendment proposed by Catholic politician Joseph Pfleger whereby the local law would be replaced by the French law on coupage. ${ }^{46}$ The following year a compromise was reached which permitted coupage on a temporary basis until 1925, and as in the case of sucrage, it was anticipated that the extension on coupage would provide a transition period to allow Alsatian and Mosellan wines to adapt to French markets. ${ }^{47}$

Discussions over the laws on Alsatian wines encompassed a range of stake-holders, from vignerons to wholesalers to political and economic elites. Views were not uniform amongst any group, and, as we have seen, divisions also emerged between Alsace and the Moselle. What was at stake in these discussions was the economic future of the region's wine industry. The return to France disrupted production for German consumers and raised questions over the future content of Alsatian wines. But the question of wine legislation became particularly contentious as it spoke to Alsace's place and position within France, thus Haegy's suggestion that Alsatian vignerons continue to produce wines for German markets proved controversial as it inferred that a French region could have its own distinct laws. For many, this situation was not possible in the French Republic that had been founded upon the principle of uniformity. What is more, Haegy's idea that Alsatian wines' 'natural' market was in Germany raised questions over the Frenchness of Alsatian wines, and, by implication, of Alsace.

In this way, wine became a symbol of disconnection. The vignerons were extremely vocal in their arguments about the failures of reintegrating the Alsatian economy into France, and discussions in the conseil consultatif stressed the 'crisis' of 'exceptional gravity' in the regional wine industry, with the wine producing populations becoming ever more discontented. ${ }^{48}$ The Syndicat of Lorrain Wine

\footnotetext{
$\overline{42}$ Letter, 25 July 1922, ADBR121AL 198 Commissaire Général de la République to Comte de Bertier, Senateur de la Moselle, Paris.

43 Letter, 1 July 1921, ADBR 121AL 1260 Syndicat du Commerce de Vins en Gros de la Lorraine, Metz.

44 Letter, 27 June 1921, ADBR 121AL 1261 Le Commissaire Général de la République to Président du Conseil, Strasbourg; Minutes, Apr. 1921, 121AL 1260 Conseil Consultatif d'Alsace et Lorraine, session d'Avril 1921. Procès Verbal.

45 Minutes, April 1921, ADBR 121AL 1260 Conseil Consultatif d'Alsace et Lorraine, session d'Avril 1921. Procès Verbal.

46 Ibid.

47 Letter, 25 July 1922, ADBR 121AL 198 Commissaire Générale de la République to Comte de Bertier, Senateur de la Moselle, Paris.

48 Minutes, Apr. 1921, ADBR 121AL 1260 Conseil Consultatif d'Alsace et Lorraine, session d'Avril 1921. Procès Verbal.
} 
Wholesalers made reference to the 'total slump' followed by the 'rapid abandonment' of Lorrain viticulture that it predicted would be the likely result of the loss of German markets to Lorrain wines, and called on the Government and Parliament to do all it could to avoid such a 'catastrophe'. ${ }^{49}$

In many ways the collapse in sales and production that followed the return to France became a symbol of the failures of reintegration, as the successes of the Alsatian economy of the years of annexation were left behind and the local economy entered a slump. Governments in Paris recognised the political importance of the problems faced by the wine industry, and their correspondence on the issue reveals that they interpreted this as a problem of national coherence. One 1919 note referred to the fact that the viticulteurs had distinguished themselves by their attachment to the French nation throughout the German 'occupation' and stressed that this represented a particularly pressing reason to ensure that they did not suffer too greatly from the return to France. ${ }^{50}$ Such political problems were inseparable from the difficult economic situation, and in spite of the attention of successive governments, the situation of the wine producers did not return to stability during the interwar years; in 1936 union leader Alexandre Eisenring of the socialist trade union, the General Confederation of Labour (confédération générale du travail; CGT), promised a crowd in Colmar that the Popular Front government would shortly be turning its attention to the ongoing problems faced by the wine growers. ${ }^{51}$

The close ties between Alsace and Germany meant that wine equally became a conduit for FrancoGerman relations, with shifts in the relationship between the two nations articulated through the politics of wine. In February 1922 the Strasbourg Chamber of Commerce reported that German customs officers were applying particularly strict surveillance of Alsatian wines on the pretext that blended wines were still being exported to Germany as 'vins d'Alsace', a label that was no longer permitted following the introduction of French wine legislation. The problem was, the General Secretary of the Chamber pointed out, that it was difficult (if not impossible) for the exporters to prove that their wines correctly labelled as 'vins d'Alsace' were not blended, and that German customs officers were taking advantage of this situation to penalise Alsatian wine makers in the context of tense FrancoGerman relations following the war and peace negotiations in Paris. ${ }^{52}$

As the Treaty of Versailles established the parameters of Franco-German relations in the period that immediately followed the war, it adopted a particularly important role in discussions of wine exports. The French government was acutely concerned that it may be accused of an infraction of the treaty following a mistake made in the labelling of any exported wine. As a result, the Strasbourg Chamber of Commerce recommended that any exporter trading with Germany should present a sample of a half litre of their wine to the Divisional Fraud Inspector, who would be able to check that the wine conformed to the law. If this was found to be the case, a certificate of origin (certificat d'origin) would be issued and the sample retained at the Chamber of Commerce until the wine had reached its destination abroad. ${ }^{53}$

In other cases, the production or distribution of wine was used to comment on how far the treaty was functioning as anticipated. In 1920 the President of the Chamber of Commerce of Mulhouse commented that the treaty exempted Alsatian and Lorrain products from customs duties upon their entry into Germany, but that it left open the possibility of the application of internal taxes. According to the President, Germany applied a special internal tax to Alsatian and Lorrain wines and beers but did not include imports from elsewhere in this law. In his view, this exceptional measure against Alsatian and Lorrain products 'went against' the spirit of the Peace Treaty. ${ }^{54}$ Franco-German relations improved from the middle of the 1920s, and once again the implications of this were reflected in the production

\footnotetext{
49 Report, 1 July 1921, ADBR 121AL 1260 Syndicat du Commerce de Vins en Gros de la Lorraine, Metz.

50 Report, 25 June 1919, ADBR 121AL 1261 Eléments de réponse à la demande de la Présidence de la République du 13 Juin, Strasbourg le 25 juin 1919.

51 Letter, 15 July 1936, ADBR 98AL 696 Prefect of the Haut-Rhin to Sous-Secrétaire d'État, Présidence du Conseil.

52 Report, 10 Feb. 1922, ADBR 121AL 1260 Chambre de commerce, Strasbourg.

53 Ibid.

54 Letter, 9 July 1920, ADBR 121 AL 1245 President of Chambre de Commerce of Mulhouse to Director of Services of Commerce and Industry, Strasbourg, Mulhouse.
} 
of wine. In 1929 German wine makers' use of Alsatian and Mosellan grapes blended to produce Rhineland and Mosel wines was described by the conservative daily La République Française as a 'success of the Peace Treaty'. ${ }^{55}$

The early 1930s witnessed the introduction of new legislation for French wine known collectively as the wine laws (statut viticole). These measures aimed to reduce wine production and maintain prices, and as Philip Whalen has pointed out, the 30 July 1935 AOC law on labelling practices was reflective of the government's support for a policy of quality over quantity, necessary to secure the loyalty of the foreign customers for French wine. ${ }^{56}$ This was a process that the Alsatian vignerons had embarked upon in 1918, although it proved a long journey for them and Alsatian wines finally received the AOC marker in 1962.

The legal and political debates over wine in interwar Alsace proved both lively and durable. While their nature reflected, in part, the interests of the diverse stakeholders involved in the discussions, they also resulted from the importance of the issues involved. Questions over the retention of local laws raised the issue of difference within a republic based upon the principle of uniformity, while wine's centrality in ideas of French culture raised questions of taste and natural market. Yet although the cultural importance of wine lent such debates an acute importance, they also presented a means for Alsatian vignerons to solve their problems. The final section charts the measures taken by the region's wine makers to present their wines as French.

\section{Wine and Culture}

The contentious political discussions about wine making in Alsace raised the issue of regional wine's natural and national character. In the nineteenth century, wine makers had increasingly stressed the links between wine and Frenchness, and during the interwar years the relationship between wine and French national identity was mobilised by the alcohol industry to present wine drinking as a 'patriotic' activity in order to encourage consumption. ${ }^{57}$ And, of course, the nature of French wine making and its close association with terroir meant that wine drinking necessarily invoked not only the nation but also the region. ${ }^{58}$ In an effort to solve the problems caused by their return to France, Alsatian vignerons aimed to create an association between place and the production of regional wine, while tying their consumption to ideas of regional and national identity.

In the first place, the production of wine helped to make Alsace a French region by tying it into the Gallic wine drinking and wine producing world, but in vignerons' efforts to alter their wine for French tastes they underlined their differences to other regional wines, which were frequently depicted as possessing natural and eternal qualities. ${ }^{59}$ The very fact that Alsatian vignerons were discussing the laws on coupage and sucrage and that they needed to alter the taste and quality of its wines for French drinkers appeared to stand in marked contrast to other regional wines. Wine, therefore, represented a symbol of Alsace's otherness within the boundaries of the hexagon, and the practicalities of wine production did not sit easily with the cult of Alsace, which had presented the region as eternally French, with the years of German rule an unwanted aberration. ${ }^{60}$

Thus, while vignerons discussed the laws governing the production of wine, efforts were made to stress the natural Frenchness of regional wine and to equate Alsatian wines with the Alsatian population. Adverts also made reference to the wine's roots in ancient Rome or amongst Gauls and criticised the German Empire for passing off Alsatian wines, which were inherently French, as a German

\footnotetext{
55 Newspaper Article, 17 July 1929, 'Un Succès de traité de paix’ La République Française.

56 Whalen, 'Insofar as the ruby wine seduces them'.

57 Sarah Howard, Les images de l'alcool en France entre 1915 et 1945 (Paris: CNRS, 2006).

58 Shanny Peer, France on Display: Peasants, Provincials and Folklore in the 1937's World Fair (Albany, N.Y.: SUNY Press, 1998.

59 Guy, When Champagne became French, 2.

60 See Karine Varley's chapter 'The Lost Provinces' in Varley, Under the Shadow of Defeat: The French War of 1870-71 in French Memory (Basingstoke: Palgrave Macmillan 2008).
} 
product. One advert lamented 'how [the] light and elegant soul [of Alsatian wines] must have suffered to be enclosed in the false bottles of the Empire, under the sinister shadow of the black Eagle'. ${ }^{6}$

Nonetheless, the tension between the taste of Alsatian wine and the cultural and economic need to present it as a French product sparked an identity crisis for the Alsatian wine industry. Its representatives attempted to resolve this tension by stressing the Frenchness of Alsatian wine and adopted a range of measures to do so. First, the various associations embarked upon discussions on the question of labelling, and how to describe the geographic origin of Alsatian wines. Vignerons and merchants debated whether regional wines should be called 'vin d'Alsace', 'vin du Rhin d'Alsace' or 'vin du Rhin français' and finally decided upon the former. This emphasised the region rather than its location beside the Rhine, and the choice of this denomination reflected the effort to forge a clear regional identity for Alsatian wine.

A crucial element of this regional image was the distinctive bottle and label adopted. A decree of 15 February 1930 enshrined the shape of the Alsatian bottle in law, while labels drew upon a longer tradition of the use of images of the region reminiscent of the late nineteenth century cult of the 'lost provinces'. This had begun during the years of annexation, and depicted a timeless, eternally French Alsace characterised by the classic regional symbols of alsaciennes (women dressed in traditional costume), half-timbered villages and storks. ${ }^{62}$ During the interwar years wine labels were designed by some of the region's most prominent artists, including Hansi, Charles Spindler and Charles Bastian. This association between regional wine and the cult of Alsace represented an important means of rooting the product in the region and the nation. The cult had served the purpose of stressing the eternal and natural Frenchness of Alsace while it was annexed by an enemy power, and the labels suggested that if this was true of the region then it was equally true of its wines.

Cultural and political elites also took measures to try to include Alsatian wines as a symbol of Frenchness alongside the storks, half-timbered houses and alsaciennes that appeared on their labels. When President of the Republic Raymond Poincaré visited the Haut-Rhin town of Riquewihr, reports focused upon the 'wine of honour' (vin d'honneur) offered to the president, upon the gift presented to him of a basket containing three bottles of wine (including one from 1865, when the town had been French) and upon his tour, which took him to house of the cooper Urweiller, which was decorated with the belongings of his son who had died fighting for France at Verdun. ${ }^{63}$ In this way, the symbolism of wine was intertwined with other elements of regional culture and identity that were mobilised to stress Alsace's shared history with France. The purpose of such efforts was to emphasise the region's eternal Frenchness, in spite of the years of German rule.

Wine makers also endeavoured to present themselves as leaders in producing quality wines, thus the Haut-Rhin town of Colmar transformed its Wine Institute (Institut viticole) into a centre of research that Mayor Edouard Richard boasted received visitors from across Alsace and the Moselle, from the interior and from abroad, and made a major contribution to the reputation of the wines of Alsace. ${ }^{64}$ And a series of local fairs were held to celebrate Alsatian wine at Ribeauvillé in 1921, Ammerschwihr in 1922, Colmar in 1927 and Molsheim in 1934. These events celebrated the wines through linking them to their terroir and tying them to the region and nation. Wine growers also attempted to underline the Frenchness of their wines in a delegation to Paris in February and early March 1928, which had the dual aim of 'expressing the joy of Alsace at its return' to France and of attempting to promote Alsatian wines within the French interior. This linking of regional economic and cultural agenda through wine festivals was cemented when Colmar became the fourth French city to host the National Festival of French Wines in 1936 (after Mâcon in 1933, Bordeaux in 1934 and Champagne in 1935). The Colmar event attempted to tie Alsatian wine to France, most notably

\footnotetext{
${ }_{61}$ Magazine, after 1918. ADBR 67, 2 Fi2/400 'Bons vins de Lorraine et d'Alsace' Editions de la Renaissance contemporaine, Paris.

62 Roland Moser, 'Les étiquettes anciennes du vin d'Alsace', Revue d'Alsace, 137 (2011), 109-34.

63 Muller, Une Civilisation de la Vigne, 272.

64 Letter, 11 Feb. 1936, ADBR 98AL 1036 Mayor of Colmar to R. Sergent, Inspecteur des Finances, Colmar.
} 
in the last day of the fair, which was marked by a procession of twenty-three carnival floats, each one representing an episode in the history of the Alsatian wine industry.

The renegotiation of the identity of local wine was, of course, part of broader efforts to stress the region's French history and cultures that took place across all realms of cultural, economic and political life after Alsace's return to France. But it also had a significant underlying economic purpose: to secure the future of the region's wine industry by stressing the Frenchness of Alsatian wines and presenting their consumption as a patriotic habit. What is remarkable in these efforts is the relative unity that efforts to present Alsatian wines as French achieved. While questions over the move from hybrid to quality plants, or over the laws on coupage and sucrage, provoked debates, there was relative unity over the efforts to stress the Frenchness of Alsatian wines. There was also remarkable consensus over the means of doing so, as vignerons tied the wines to the cult of Alsace and associated them with other regional symbols that were indelibly linked to Frenchness in the national imagination. What this unity suggests is the potency that the association between wine drinking and Frenchness had achieved by 1918. This work had been done in the early years of the Third Republic and did not leave space for an alternative presentation of Alsatian wines. As a result, the cultural power of wine appeared to offer a solution to the wine industry's economic and political problems, and it allowed the Alsatian vignerons to survive the transformation and adaptation to French markets during the interwar years.

\section{Conclusion}

Adolphe Walter's 1933 discussion of the Alsatian wine industry after 1918 opened with the words 'L'Alsace est par excellence un pays viticole'. ${ }^{65}$ Indeed, wine was an important part of the regional economy, but Walter's words also hint at the particular political importance that this product adopted after 1918. In stressing the centrality of wine in Alsace, he presented the drink as a symbol of Alsace's natural place within France, the ultimate wine producing country. In other words, Alsatian wine was a symbol of the region's natural and eternal Frenchness.

The problem for Alsatian vignerons was that the reality was not so straightforward. Fifty years of producing wine for German consumers meant that their wines were not to the taste of French drinkers, and the need to realign their wines to French markets provoked lively debates about the best means to do so. These debates reflect the broader process of reintegration, where a range of different stakeholders offered divergent views on return and a multi-cornered struggle emerged. But the history of wine also reveals a new, sensory dimension to the means by which the problems associated with return entered French popular consciousness; through the consumption of Alsatian wine French drinkers became aware of Alsace's otherness as they tasted Germany in what they expected to be bottles of French wine. In this way, the history of the Alsatian wine industry offers an insight into the multiple small-scale cultural processes whereby understandings of difference develop.

While many vignerons believed that Alsace belonged within France and were keen to facilitate the process of reintegration, a primary aim for all of the stakeholders involved in the discussions over wine making was securing the wine industry's success. The history of Alsatian wine between the wars reveals the mobilisation of the cultural capital of wine for economic purposes. For Alsatian vignerons this strategy was based upon the linking of their regional products with understandings of identities that spoke to Alsace's natural place within France. As we have seen, this reflected the solution that wine offered to broader economic and political problems, but it is also suggestive of the power of alcohol to act as a shorthand for national and regional identities. Given that Alsatian vignerons were seeking customers and markets in France, the identity that they constructed was outward facing and reflected dominant ideas about Alsace in French national culture, most notably through the images of the late nineteenth-century cult of Alsace.

The history of the wine industry in Alsace after 1918, therefore, has implications for our understanding of the construction and evolution of identities and expressions of belonging. The

$\overline{65}$ Walter, 'Le vin', 175. 
juxtaposition of wine drinking France with beer drinking Germany by contemporaries represented a stark and emotive illustration of the differences between the two nations, which was also an important currency in political debate. ${ }^{66}$ Vignerons' attempts to present Alsatian wines as naturally and eternally French recalled earlier efforts to do the same with other regional wines, but the situation was different in Alsace. The initiatives taken by Alsatian vignerons after 1918 took place against the backdrop of widespread acceptance of the Frenchness of other regional wines, which had been built while Alsace was part of Germany. There was thus a tension between the practical efforts to make Alsatian wine palatable to French drinkers and the presentation of the wine as naturally and eternally French, but vignerons achieved remarkable consensus in their association of Alsatian wine with the symbols of the cult of Alsace. In this way, wine's cultural capital in twentieth-century France created a shorthand that allowed Alsatian wine to at once express the region's Frenchness, while also promoting its consumption within the region and across the Vosges.

Acknowledgements. I would like to thank all the participants in the Eating and Drinking Network workshops at the University of Saint Andrews for the fruitful and thought provoking discussions that helped this research to take shape, with particular thanks to Kate Ferris and Andrew Smith for their insights. I would also like to extend my strongest thanks to the anonymous referees at Contemporary European History for their helpful, thoughtful and constructive comments on earlier drafts of the article.

${ }_{66}$ Michael Nolan, The Inverted Mirror: Mythologizing the Enemy in France and Germany, 1898-1914 (New York and Oxford: Berghahn Books, 2004).

Cite this article: Carrol A (2020). Wine Making and the Politics of Identity in Alsace, 1918-1939. Contemporary European History 29, 380-393. https://doi.org/10.1017/S0960777320000375 